\title{
Dark Events of the Istrian Countryside: An Electronic Media Perspective
}

\author{
Metod Šuligoj \\ University of Primorska, Faculty of Tourism Studies - Turistica, Slovenia \\ metod.suligoj@fts.upr.si
}

This pilot research illuminates the connection and reflection of past traumatic events in contemporary dark events. The purpose of the research is to provide a basic understanding of what dark events and dark tourism mean in a specific regional environment - the countryside of the trans-border region of Istria. Consequently, the media-constructed social reality related to dark events was identified with the help of a quantitative content analysis; cross tabulation and descriptive analyses were employed to resolve three research questions. It was found that WW I I-related memorial services dominate in all areas of the Istrian countryside; dark events, according to media, mostly occurred at memorials or internment sites; most of them were in small Istrian towns. Flower ceremonies and cultural programmes are essential elements of Istrian dark events in all areas. However, there is no statistically significant association between event type and different rural areas. Consequently, we are now (at least basically) familiar with current Istrian dark events, which offer an ideal basis for the development of dark tourism in the most developed tourist region of Slovenia and Croatia.

Keywords: dark events, dark tourism, thematic tourism, Istrian history, countryside, media

https://doi.org/10.26493/2335-4194.12.121-132

\section{Introduction}

Contemporary tourists seek tailored tourist experiences with different immaterial qualities as a reaction to post-modern urban life (Robinson \& Novelli, 2005; Šuligoj, 2018, p. 19; Trauer, 2006; Wong \& Cheung, 1999). Consumers as tourists can thus encounter differentiated thematic tourism products as a reaction to tourist demand or as products which, in contrast, create demand (Douglas, Douglas, \& Derrett, 2001; Kruja \& Gjyrezi, 2011; Štetić, Šimičević, \& Curčić, 2013; Trauer, 2006) and, consequently, 365-day tourism destinations.

It is worth mentioning that many terms are used in thematic tourism theory: 'niche tourism' (Robinson \& Novelli, 2005), 'selective forms of tourism' (Štetić et al., 2013) or 'special interest tourism' (Douglas et al.,
2001). 'Special interest tourism,' as the predecessor of 'niche tourism,' which was conceptualised during the 1980 os (Hall \& Weiler, 1992) and is the complete opposite of mass tourism (Douglas et al., 2001, p. 2; Hall \& Weiler, 1992) accelerated in the second half of the 2 oth century. It as part of the interdisciplinary system of the 21st century, which encompasses all elements of supply and demand in the broadest sense, including 'political, economical, ecological, technological, and socioeconomical and socio-cultural concerns, from the local to the global level' (Trauer, 2006, p. 185).

Consequently, 'special interest tourism' can be related to the so-called homo turisticus, who is seeking experiential dimensions based on numerous possibilities of tourist services (Šuran, 2016, p. 69) and is aimed at increasing consumption. Tourists, among 
other things, also look for interesting/exciting memorial sites with an (extreme) traumatic background that shapes contemporary societies only in a certain geographical area or wider on the international level, e.g., sites related to the Holocaust or other genocides and criminal acts. Interestingly, tourists, however, do not necessarily understand such sites or events (Kennell, Šligoj, \& Lesjak, 2018, p. 948). This is even more important if we consider the fact that visiting such sites is not necessarily understood, even among local residents as part of tourism, which Šuligoj (2016; 2017) found in his investigation among young residents in Croatia. However, many dark events and dark tourism sites were and still are interesting for the media. The media construct social reality through the explanation and interpretation of information (Nišić \& Plavšić, 2014). Moreover, the media can generate a culturally distributed collective memory (Pavlaković \& Perak, 2017, p. 301), and be the 'site of memory' (Mustapić \& Balabanić, 2018, p. 439), 'the media plays a huge role when it comes to dark tourism as it contributes to the popularization of sites;' 'this could result in overcommercialisation of dark tourism sites and these sites becoming a spectacle' (Simone-Charteris, Kirkpatrick, \& McLaughlin, 2018, p. 73).

This pilot research illuminates the connection and reflection of past traumatic events in contemporary memorial practices with some perceived tourist characteristics (or at least potentials for tourism development). The research aims to add a new dimension to social studies and humanities in providing a pilot analysis of history-centric memorial practices and dark tourism. More specifically, the purpose of the research is to provide a basic understanding of what dark events and dark tourism mean in a specific regional environment: the countryside of the trans-border region of Istria (Slovenian and Croatian part). A dark event, as a construct used in this research, concurrently reflects the memorial and dark tourism dimension and derives from the dark event typology of Frost and Laing (2013, pp. 36-42) and Kennell et al. (2018, p. 948).

According to the research purposes and after the finished state-of-the-art (see chapters 'Brief Theoretical Background: Dark Events and Dark Tourism’ and 'Brief Historical Background: Traumatic 2oth Century in Istria'), we want to identify the media-constructed social reality related to dark events as a significant part of contemporary social life (which includes tourism) in Istria. In addition, the second objective is to identify contemporary types, time components, and locations where public history-centric dark (memorial) events take place in the Istrian countryside. Consequently, a content analysis as a useful methodological approach in social sciences, where its growing 'popularity' is evidenced in several top quality scientific publications (Neuendorf, 2017, p. xv, 4), was employed. Specifically, we refer to a quantitative content analysis, which is 'analysis of documents and texts that seeks to quantify content in terms of predetermined categories and in a systematic and replicable manner' (Bryman, 2012, p. 290).

The coding unit was an article as an independent electronic media entity (e-newspaper). Each article was coded according to predetermined codes (indicators); see Tables 2 and 4 . Codes represented categorical variables with no multiple responses allowed. The coding process was done entirely by one researcher. All quantitative methods (cross tabulation and descriptive analyses) were employed using SPSs Statistics 24.0.

Quantitative content analysis is most efficient when dealing with specific research questions (Bryman, 2012, p. 291; Riffe, Lacy, \& Fico, 2005, pp. 43-45), which led us to formulate the following research questions:

$R Q 1$ What are the main characteristics of Istrian dark events that can be defined on a media basis?

RQ2 Are dark events of different types associated with areas?

$R Q 3$ When do Istrian dark events occur or when do the media reports on them?

This research builds on some of the previous research related to Istrian/Upper Adriatic memory, e.g., Ballinger (2002), D'Alessio (2012), Hrobat Virloget (2015), Hrobat Virloget and Čebron Lipovec (2017), or past commemorative practices, e.g., Klabjan (2010) and Cattunar (2012), including those focused on the legacy of Isonzo/Soča front, e.g., Kavrečič (2017), Todero (2010) as well as to some other contemporary studies, e.g., Gosar, Koderman and Rodela (2015). 


\section{Brief Theoretical Background:} Dark Events and Dark Tourism

Tragic and morbid topics, in general, constitute a relevant reason for travel, which makes this activity a tourist activity within so-called dark tourism. Tarlow (2005, p. 48) described dark tourism as 'visitations to places where tragedies or historically noteworthy death has occurred and that continue to impact our lives,' while Preece and Price (2005, p. 192) defined it as 'travel to sites associated with death, disaster, acts of violence, tragedy, scenes of death and crimes against humanity.' However, the first definitions of Foley and Lennon (1996, p. 198) define it as 'the presentation and consumption (by visitors) of real and commodified death and disaster sites', or as 'the visitation to any site associated with death, disaster and tragedy in the twentieth century for remembrance, education or entertainment' (1997, p. 155), or as 'tourism associated with sites of death, disaster, and depravity' (Lennon \& Foley, 1999, p. 46). Very relevant and interesting are also two of Stone's definitions: dark tourism is 'the act of travel to sites associated with death, suffering and the seemingly macabre' (2006, p. 146) and later 'dark tourism is concerned with encountering spaces of death or calamity that have political or historical significance, and that continue to impact upon the living' Stone (2016, p. 23). All these definitions (and some others, e.g., Ashworth, 2008, p. 234; Robb, 2009, p. 51) indicate the breadth of the research area, as well as its essence, which is human death and suffering. Foundational monograph of Lennon and Foley entitled Dark Tourism: The Attraction of Death and Disaster (Lennon \& Foley, 2000) conceptualised dark tourism as a subset of cultural tourism and shifted it conceptually from heritage tourism (Bowman \& Pezzullo, 2010; Kravanja, 2018).

The term 'dark tourism' is not the only one to define the tourism-death connection. The following terms are also related to the connection between tourism and death, which are not fully synonyms: holidays in hell (O'Rourke, 1988), thanatourism (Seaton, 1996, p. 240), morbid tourism and an attraction-focused artificial morbidity-related tourism (Blom, 200o), sombre tourism (Butcher, 2003; Hughes, 2008), fright tourism (Bristow \& Newman, 2005), atrocity tourism (Ash- worth \& Hartmann, 2005), grief tourism (Dunkley, Morgan, \& Westwood, 2007), conflict heritage tourism (Mansfeld \& Korman, 2015), genocide tourism (R. A. Dunkley et al., 2007), trauma tourism (Clark, 2006), war-related tourism (Bigley, Lee, Chon, \& Yoon, 2010), post-war tourism (Wise, 2011), war tourism (Keyes, 2012), warfare tourism (Šuligoj, 2016; 2017), battlefield tourism (Dunkley, Morgan, \& Westwood, 2011; Ryan, 2007), tourism of memory (Hertzog, 2012), or memorable tourism (Drvenkar, Banožić, \& Živić, 2015; Kim, 2013), favela tourism, (Robb, 2009), atomic or nuclear tourism (Freeman, 2014; Gusterson, 2004) and dystopian dark tourism (Podoshen, Venkatesh, Wallin, Andrzejewski, \& Jin, 2015). The term 'dark tourism' is the most frequently searched tourismrelated keyword in the developed countries of North America, Europe, and Australia (see https://trends .google.com).

Kennell et al. (2018), in contrast, focused only on so-called dark events, which are not exclusively related to the dark tourism context. They adopted Frost and Laing's (2013, pp. 36-42) typology and listed: (a) dark exhibitions, (b) dark re-enactments, e.g., annual reenactment of the battles, (c) national days of mourning or remembrance, (d) memorial services, opening of memorials, concerts, performances, (e) significant anniversaries, e.g., centenaries, (f) parades, marches, processions, (g) festivals. Moreover, Getz's (2008, p. 404), Frost and Laing's (2013, pp. 36-42), and Kennel et al's (2018, pp. 947-949) descriptions of commemorative events as one kind of cultural celebrations related to the traumatic heritage/past as well as to the typology of the related events were also relevant/interesting for this research. Such events are usually designed to remember victims and historical tragic events and are carried out close to the memorial (Rojek, 1994) or dark tourism sites; consequently, we link them directly to the dark tourism. Dark tourism sites, which are also event venues, are according to Seaton (1996) (a) sites of public executions, (b) sites of individual or mass deaths: areas of former battlefields, death camps and sites of genocide and similar, (c) memorials or internment sites, (d) sites/areas with the purpose of viewing evidence of death or symbolic representations of it and (e) places or events of re-enactments or simulation of 
death. However, in general, events ad these sites 'are often highly significant occasions for local communities and might not be understood by tourists' (Kennell et al., 2018, p. 948). In the Istrian case, contemporary memorial and dark tourism practices have not been investigated, and we also do not know how much they are present in the (regional) media.

\section{Brief Historical Background: Traumatic 2oth Century in Istria}

After the ruin of the Venetian Republic, and finally with the Congress in Vienna (1815), the Istrian peninsula was annexed to the Habsburg Empire. In 1853, Vienna declared Pula to be the empire's principal military port, which changed the city from an unimportant and inconsequently fishing village to one of Europe's more prominent naval bases; none of the following regimes accomplished as much in developing the city (Duda, 200o; Marsetič, 2013, pp. 483, 484). All this development led to an intense militarisation as well as the systematic urban planning and economic development of Pula and the entire southern Istrian peninsula (Marsetič, 2013). In terms of culture and entertainment, Pula was also extremely advanced; see Kalčić (2016) and Duda (200o). However, Pula was differed from the rest of the region by presence of the army, cultural abundance, and economic prosperity, while the people of rural areas lived in poverty; see Knez (2010) and Marsetič (2014). The clash with the Kingdom of Italy in 1915 (WwI) halted the development of the city/region.

Shortly before the war, in the summer of 1914, a civil steamboat, Baron Gautsch, sank south of Rovinj after entering the minefield of the Austro-Hungarian Navy, which was intended to defend the Imperial Navy from the sea (Spirito, 2002). During the WwI, Pula was bombed 41 times by Italian military aviators (Mandić, 2006, pp. 210-212), while other areas of the peninsula were not endangered/damaged. Residents of Istria, especially in 1917, suffered from hunger, which combined with diseases and dangerous living conditions led to emigration/evacuation (Herman Kaurić, 2015, p. 14). According to the Treaty of Rapallo signed on 12 November 1920, almost all territory of the former Austrian Littoral, including Istria, was annexed to the
Kingdom of Italy (Lipušček, 2012; Šuligoj, 2015a). A great socio-economic crisis in the Pula and the whole peninsula (Marsetič, 2006b; 2006a), which, together with the state fascist terror, led to an increased emigration of the Slavic population and Italian antifascists (Dukovski, 2010; Hrobat Virloget \& Čebron Lipovec, 2017, p. 47; Violante, 2009, p. 98); Slavic rebels as well as native local Italians of different political ideologies were persecuted by the fascists due to their common work in an antifascist coalition movement (Ashbrook, 2006; Violante, 2009). Moreover, systematic 'ethnic refinement' of the population was upgraded by the organised immigration of the 'true Italians' from other parts of the kingdom, which additionally influenced the change in the ethnic structure in Istria.

Resistance from the beginning of World War Two onwards was escalated and transformed into a severe armed conflict with the fascist Italian army. After the capitulation of Italy in September 1943, Istria became part of a German Province under the name of the Operational Zone of the Adriatic Littoral (Ferenc, 1966). The tragedy of the occupation was also marked by the deportation of more than 20,000 Istrians to the Nazifascist concentration camps, from which more than 5,000 never returned; 5,000 Istrian Partisan fighters did not survive WWII (Jokić \& Čudov, 1986, p. 417). The liberation of the Istrian peninsula was a military action of the anti-fascist resistance movement led by the Yugoslav Partisans (see Beltram, 2017, and Dukovski, 2001; 2011), which Istrians of Italian origin also were involved.

After wWII, pro-Italian forces launched a campaign to blame Tito and his followers for the violence and encouraged the Istrian Italians (both native to the area and those that had immigrated) towards emigration (Altin \& Badurina, 2017; Dukovski, 2010; Kosmač, 2018). Mass executions of (former) fascists and their followers, capitalists, possessors, and Roman Catholic priests by Tito's army, mostly known as foibe (Altin \& Badurina, 2017; D’Alessio, 2012; Radošević, 2010) (from the Italian word infoibare means throwing into the abyss) caused additional upheaval. ${ }^{1}$ The victims

\footnotetext{
${ }^{1}$ Chasms and foibe are characteristic for the all Upper Adriatic karst landscape.
} 
of the foibe and the socialist revolution were systematically denied up to the democratic changes of the 1990s.

On the international level, there were considerable disagreements in determining the Italian-Yugoslav state border (Kosmač, 2018). With the Paris Peace Treaties signed in 1947, Italy had to cede most of the Istrian peninsula to Yugoslavia; north of the River Mirna, including the province of Trieste, became the so-called Free Territory of Trieste (Dukovski, 2010; Kosmač, 2018; Rogoznica, 2011; Tunjić, 2004; Violante, 2009). The border issue with Italy was resolved no earlier than in 1954 and finally confirmed with the Treaty of Osimo (1975): the whole Istrian peninsula South of Muggia (Milje), was officially annexed to Yugoslavia (Tunjić, 2004). Istria in the (Second) Yugoslavia was divided between the two (socialist) republics, Slovenia and Croatia. The new political regime and the systematic immigration of Slavic people from other Yugoslav republics, significantly influenced the socio-economic development of the region (see Purini, 2012; Hrobat Virloget; and Šarić, 2015). Istria faced an imbalanced development of coastal and some other towns/cities (tourist and industrial centres) and the rural interior of the region. This resulted in the economic stagnation and depopulation of central Istria, where agriculture prevailed.

The last military conflict in the 2oth century in Europe was the Yugoslav/Balkan conflict. The Croatian homeland war in Istria was not as intense and bloody as in some other areas. The Croatian part of Istria was 'liberated' by the end of 1991 without a serious direct military clash (Majušević, 2012, p. 446). The Slovenian ten-day war did not reach the scale of the Croatian one. However, there were three brief military confrontations of the Slovenian police and Territorial defence forces with the Yugoslav People's Army in the Istrian countryside: in the hamlet of Moretini, at the (then) Bivje intersection, and at the Škofije international border-crossing. These three confrontations resulted in five wounded and three dead Yugoslav People’s Army soldiers (Filipčič, 2011, pp. 22, 23).

Istria, which was the leading tourist region as early as in the period of post-WWII Yugoslavia (Blažević, 1984, p. 5), has been maintaining status and still has highly recognisable tourism products on the international level (e.g., sports events, cultural events, many secular and sacral buildings from the Venetian, Austrian and Italian periods, Tito's and other heritage on the Brijuni Islands, traditional gastronomy, the former Parenzana railroad track, and similar), what is, in terms of development from the 19th century onwards, described by Blažević $(1984 ; 1987)$ and Šuligoj $(2015 b){ }^{2}$ Concurrently, because of its geostrategic position, the multi-ethnical Istria was an area of constant conflict and an area with reinforced military presence. Today, in contrast, it is a recognisable Upper Adriatic area of peace, collaboration and coexistence, although, according to Cocco (2010), it remains deeply subjected to Central European, Roman and Balkan influences. It seems that the French slogan Liberté, égalité, fraternité, is also alive in Istria in the late zoth century and especially at the beginning of the 21st century, although not without problems. Traumatic historical events of the 2oth century with frequent changes in power affected Istria's residents in urban and rural areas. Consequently, this territory evolved over years to become the South-European hotspot. This creates different public memorial practices and different memorial sites, which offer typical examples, which are nowadays linked also to dark tourism. They are scattered around Istrian (coastal) cities as well as in the countryside, which is generally less overloaded with tourism, but traumatic situations (clashes, executions, torture, etc.) were taking place there as well. This offers new development opportunities for rural tourism. In terms of dark tourism, this has not been studied.

\section{Contemporary Dark Events in the Istrian Countryside}

After WWI, WWII, and after all totalitarian regimes, the events, heroes and victims of the Yugoslav/Balkan conflict in the 1990 are commemorated in Istria. As mentioned before, Istrian memorial and dark tourism practices have not been investigated, and we also do

\footnotetext{
${ }^{2}$ The roots of modern development date back to the Habsburg period; more can be found in Kavrečič (2009; 2011; 2015) or Baskar (2010).
} 


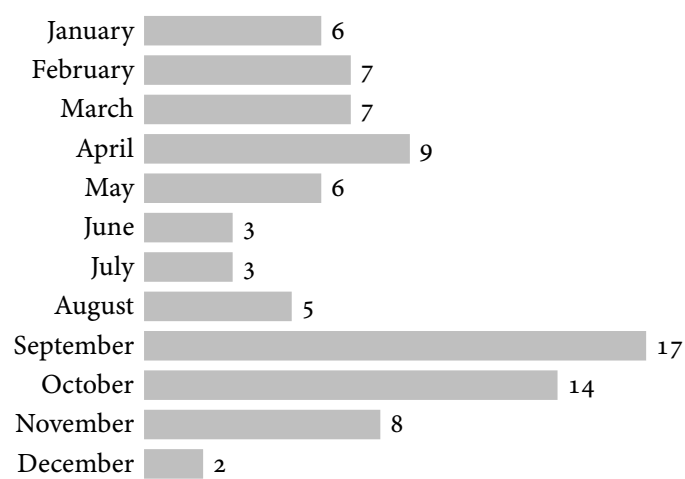

Figure 1 Dark Events Distribution by Months

not know how much they are present in the (regional) media. Thus, three leading regional newspapers were selected: Primorske novice in Slovenian, Glas Istre in Croatian, and La voce del popolo in the Italian language (all available in printed and electronic versions). They were selected on the basis of preliminary short informal interviews with eleven people of different ages in Slovenian and ten in Croatian Istria.

Regional media are more familiar with the local mentalities and historical moments than others are. All available articles from 1 February 2016 to 30 November 2018 were included in the analyses, which totals 126 articles. All articles were particularly focused on history-centric dark events; commemorations of 1 November ${ }^{3}$ or scientific events were not included. Basic characteristics of analysed articles are presented in Table 1. Figure 1 shows the time distribution of articles on dark events in the Istrian countryside. As we can see, they were unevenly dispersed throughout the year; from this point of view, they are not touristcentric. Articles on off-summer season events (April, September, October and November) are particularly interesting. ${ }^{4}$ This is coherent with the idea of 365 -days tourism destinations, if dark events link with the dark tourism context, as well as to thematic tourism theory. This finding provides an answer to RQ3.

In the following phase, all selected articles were

${ }^{3}$ Known as All Saints' Day, All Hallows' Day or the Day of the Dead.

${ }^{4}$ It should be noted that articles in electronic media are published on the day of event, or a day or two later.
Table 1 Characteristic of Analysed Articles

\begin{tabular}{llrr}
\hline Category & Item & $f$ & $\%$ \\
\hline (Q1) Newspaper & Glas Istre & 82 & 65 \\
& La voce del popolo & 30 & 24 \\
& Primorske novice & 14 & 11 \\
\hline (Q5) Report type & Short message & 30 & 24 \\
& A shortened version & 5 & 4 \\
& of the printed report & & \\
& Full text & 91 & 72 \\
\hline (Q6) Number & No photos & 4 & 3 \\
of photos & One photo & 92 & 73 \\
& More than one photos & 30 & 24 \\
\hline (Q7) What kind & Only old/historical & 3 & 2 \\
of photos? & Only new photos & 118 & 94 \\
& Both new and historical & 1 & 1 \\
\hline
\end{tabular}

coded (see introductory chapter) and then analysed. Table 2, which is result of cross-tabulation $\left(\chi^{2}\right.$ Test of Independence) analysis with Fisher exact test $(F I(x))$, shows that history-centric dark events (according to regional media) mainly occurred in rural areas $\left(\sum\right.$ $=69 \%$ ), if small old Istrian towns can also be classified as rural areas. Moreover, memorial services as an event type significantly dominate in all types of areas, for which dark exhibitions should also be mentioned as the second-largest type of event in Istrian media. Surprisingly, there are a small number of articles on events in the non-settlement area, although the main military clashes (and thus casualties) usually take place there; the already mentioned foibe are also located there; villages represent the second smallest group of event venues. Nevertheless, according to results in Table 3, based on media articles there is not enough evidence to suggest an association between event type and area: $F I(x)=7.947$ and exact $p=0.479$ (if $p \leq 0.05$ it is significant). This empirical finding gave us an answer to RQ2.

After the completion of the first analysis, a simple cross tabulation was employed for additional description of dark events in the Istrian countryside. As a result, Table 4 shows the main characteristics of dark events in the Istrian countryside. It is necessary to take 
Table 2 Articles on Type of Area in Relation to Events Type

\begin{tabular}{|c|c|c|c|c|c|c|}
\hline Event type & Item & (1) & $(2)$ & (3) & (4) & (5) \\
\hline \multirow[t]{4}{*}{ Dark exhibition } & Count & 4 & 5 & 3 & o & 12 \\
\hline & Percentage within event type & 33 & 42 & 25 & o & 100 \\
\hline & Percentage within area & 10 & 12 & 8 & o & 10 \\
\hline & Percentage of total & 3 & 4 & 2 & o & 10 \\
\hline \multirow[t]{4}{*}{ National day of Mourning or Remembrance } & Count & 5 & 5 & 1 & o & 11 \\
\hline & Percentage within event type & 46 & 46 & 9 & o & 100 \\
\hline & Percentage within area & 13 & 12 & 3 & o & 9 \\
\hline & Percentage of total & 4 & 4 & 1 & o & 9 \\
\hline \multirow[t]{4}{*}{ Memorial service } & Count & 27 & 30 & 32 & 9 & 98 \\
\hline & Percentage within event type & 28 & 31 & 33 & 9 & 100 \\
\hline & Percentage within area & 69 & 71 & 89 & 100 & 78 \\
\hline & Percentage of total & 21 & 24 & 25 & 7 & 78 \\
\hline \multirow[t]{4}{*}{ Significant anniversary } & Count & 3 & 2 & o & o & 5 \\
\hline & Percentage within event type & 60 & 40 & o & o & 100 \\
\hline & Percentage within area & 8 & 5 & o & o & 4 \\
\hline & Percentage of total & 2 & 2 & o & o & 4 \\
\hline \multirow[t]{4}{*}{ Total } & Count & 39 & 42 & 36 & 9 & 126 \\
\hline & Percentage within event type & 31 & 33 & 29 & 7 & 100 \\
\hline & Percentage within area & 100 & 100 & 100 & 100 & 100 \\
\hline & Percentage of total & 31 & 33 & 29 & 7 & 100 \\
\hline
\end{tabular}

Notes Column headings are as follows: (1) city, (2) town, (3) village, (4) non-settlement area, (5) total.

Table 3 Statistical Significance

\begin{tabular}{lccrr}
\hline Item & $(1)$ & $(2)$ & $(3)$ & $(4)$ \\
\hline Pearson Chi-Square & $9.604^{*}$ & 9 & 0.383 & 0.378 \\
Likelihood Ratio & 13.052 & 9 & 0.160 & 0.222 \\
Fisher's Exact Test & 7.947 & & & 0.479 \\
Linear-by-Linear Assoc. & $0.843^{\star *}$ & 1 & 0.359 & 0.389 \\
No. of Valid Cases & 126 & & & \\
\hline
\end{tabular}

Notes Column headings are as follows: (1) value, (2) degrees of freedom, (3) asymptotic significance (2-sided), (4) exact significance (2-sided).

into account once again that the following findings, as well as previous ones, rely on media-constructed reality in Istria.

Of the analysed regional electronic media arti- cles, 44 report that dark events occurred at memorials or internment sites and 19 at sites of individual or mass deaths. Most of them were in towns. Events were history-centric with WWII as a background significantly dominating in all areas. It should be taken into consideration that WWII still represents the most extensive and traumatic armed conflict of the 2oth century in Istria; events that relate to the victims of fascist terror could be added as well. Flower ceremonies, as a significant component of the programme, were pointed out in 54 articles, which clearly highlights their importance. Similarly, a speech, as the simplest event programme element, is reported in 43 articles, while more varied cultural programmes were found in 36 articles. They were the most frequent programme type in villages and towns where events occurred; see Table 4. These provide an answer to RQ1. 
Table 4 Characteristics of Dark Events in the Istrian Countryside

\begin{tabular}{|c|c|c|c|c|c|c|}
\hline Event type & Item & & (1) & (2) & (3) & (4) \\
\hline \multirow[t]{6}{*}{ Site category } & \multirow[t]{2}{*}{ Site of individual or mass deaths } & Count & 3 & 12 & 4 & 19 \\
\hline & & Percentage & 16 & 63 & 21 & 100 \\
\hline & \multirow[t]{2}{*}{ Memorials or internment site } & Count & 22 & 18 & 4 & 44 \\
\hline & & Percentage & 50 & 41 & 9 & 100 \\
\hline & \multirow{2}{*}{$\begin{array}{l}\text { Site/area with the purpose of viewing evidence } \\
\text { of death or symbolic representations of it }\end{array}$} & Count & 3 & 1 & 0 & 4 \\
\hline & & Percentage & 75 & 25 & o & 100 \\
\hline \multirow[t]{12}{*}{ Conflict } & \multirow[t]{2}{*}{ WWI } & Count & 3 & 4 & 1 & 8 \\
\hline & & Percentage & 38 & 50 & 12 & 100 \\
\hline & \multirow[t]{2}{*}{ Fascist terror } & Count & 2 & 5 & o & 7 \\
\hline & & Percentage & 29 & 7 & o & 100 \\
\hline & \multirow[t]{2}{*}{ WWII } & Count & 21 & 23 & 7 & 51 \\
\hline & & Percentage & 41 & 45 & 41 & 100 \\
\hline & \multirow[t]{2}{*}{ Socialist revolution and Italian exodus } & Count & 5 & 1 & o & 6 \\
\hline & & Percentage & 83 & 17 & o & 100 \\
\hline & \multirow[t]{2}{*}{ Independence war in the 1990 s } & Count & 8 & 2 & 1 & 11 \\
\hline & & Percentage & 73 & 18 & 9 & 100 \\
\hline & \multirow[t]{2}{*}{ Other } & Count & 3 & 1 & o & 4 \\
\hline & & Percentage & 75 & 25 & o & 100 \\
\hline \multirow[t]{6}{*}{ Cultural programme } & \multirow[t]{2}{*}{ Just a speech } & Count & 25 & 14 & 4 & 43 \\
\hline & & Percentage & 58 & 32 & 9 & 100 \\
\hline & \multirow[t]{2}{*}{ Varied cultural programme } & Count & 11 & 17 & 3 & 31 \\
\hline & & Percentage & 35 & 55 & 10 & 100 \\
\hline & \multirow[t]{2}{*}{ Not specified ${ }^{*}$} & Count & 6 & 5 & 2 & 13 \\
\hline & & Percentage & 46 & 38 & 15 & 100 \\
\hline \multirow[t]{6}{*}{ Flower ceremony } & \multirow[t]{2}{*}{ Yes } & Count & 23 & 24 & 7 & 54 \\
\hline & & Percentage & 43 & 44 & 13 & 100 \\
\hline & \multirow[t]{2}{*}{ No } & Count & 8 & 3 & o & 11 \\
\hline & & Percentage & 73 & 27 & o & 100 \\
\hline & \multirow[t]{2}{*}{ Not specified ${ }^{*}$} & Count & 11 & 9 & 2 & 22 \\
\hline & & Percentage & 50 & 41 & 9 & 100 \\
\hline
\end{tabular}

Notes Column headings are as follows: (1) city, (2) village, (3) non-settlement area, (4) total. * It was not clearly specified by the journalist.

\section{Conclusion}

Dark tourism studies focus on the relationships between still-living generations of visitors and sites of traumatic death. At these sites, dark events with simple or varied programmes occur today, which can be a special type of thematic tourism. Consequently, according to the purposes of this research (i.e., to provide a basic understanding of what dark events and dark tourism mean in a specific regional environment) dark tourism and the Istrian history in the 2oth century 
were initially briefly described. On this basis, three research questions were defined. Six indicators (time distribution, event type, site category, conflict, cultural programme and flower ceremony) served as robust directions for the empirical analysis. It was determined that WWII-related memorial services are the dominating ones in all areas of Istrian countryside; dark events, according to media, mostly occurred at memorials or internment sites; most of them were in towns. Flower ceremonies and cultural programme are significant elements of Istrian dark events in all areas. However, there is no statistically significant association between event type and different rural areas, which also applies when the urban environment is considered. These results, which reflect the media-constructed social reality related to dark events, gave provide to all research questions (RQ1-RQ3).

The value of this pilot research is that different Istrian history-centric dark events reported in regional electronic media were identified and then described, which represents an original perspective in dark tourism studies (especially in the post-Yugoslav states). Consequently, we are now (at least basically) familiar with the present Istrian dark events, which offer an ideal base for the development of dark tourism in the most developed tourist region of Slovenia and Croatia.

However, this research has also certain limitations and weaknesses that need to be mentioned. First, the pilot research is done on the basis of electronic media, which include only limited indicators/characteristics, which means that this is not a comprehensive analysis. Second, dealing with categorical variables limits statistical analyses. Hence, the number of analysed research units can affect the results; furthermore, this analysis relies on the population. However, there was a possibility that some articles could be unintentionally overlooked. Nevertheless, there should not be a significant discrepancy between the real and the analysed number of articles.

\section{References}

Altin, R., \& Badurina, N. (2017). Podijeljeno pamćenje: istarski egzodus u urbanom prostoru Trsta. Časopis za suvremenu povijest, 49(2), 317-338.
Ashbrook, J. (2006). 'Istria is ours, and we can prove it:' An examination of Istrian historiography in the nineteenth and twentieth centuries. The Carl Beck Papers in Russian and East European Studies, 1707, 1-39.

Ashworth, G. (2008). The memorialization of violence and tragedy: Human trauma as heritage. In B. Graham \& P. Howard (Eds.), The Ashgate research companion to heritage and identity (pp. 231-244). Aldershot, England: Ashgate.

Ashworth, G., \& Hartmann, R. (2005). The management of horror and human tragedy. In G. Ashworth \& R. Hartmann (Eds.), Horror and human tragedy revisited: The management of sites of atrocities for tourism (pp. 253262). New York, NY: Cognizant.

Ballinger, P. (2002). History in exile: Memory and identity at the borders of the Balkans. Princeton, NJ: Princeton University Press.

Baskar, B. (2010). Southbound, to the Austrian riviera: The Habsburg patronage of tourism in the Eastern Adriatic. Anthropological Notebooks, 16(1), 9-22.

Beltram, V. (Ed.). (2017). Slovenska Istra v boju za svobodo. Koper, Slovenia: Združenje protifašistov, borcev za vrednote Nов in veteranov Koper.

Bigley, J. D., Lee, C.-K., Chon, J., \& Yoon, Y. (2010). Motivations for war-related tourism: A case of DMZ visitors in Korea. Tourism Geographies, 12(3), 371-394.

Blažević, I. (1984). Turizam Istre. Zagreb, Croatia: Savez geografskih društava Hrvatske.

Blažević, I. (1987). Povijest turizma Istre i Kvarnera. Opatija, Croatia: IRo Otokar Keršovani.

Blom, T. (2000). Morbid tourism: A postmodern market niche with an example from Althorp. Norwegian Journal of Geography, 54(1), 29-36.

Bowman, M. S., \& Pezzullo, P. C. (2010). What's so 'dark' about 'dark tourism'? Death, tours, and performance. Tourist Studies, 9(3), 187-202.

Bristow, R. S., \& Newman, M. (2005). Myth vs. fact: An exploration of fright tourism. In Proceedings of the 2004 Northeastern Recreation Research Symposium (pp. 215221). Newtown Square, PA: Us Department of Agriculture / Forest Service / Northeastern Research Station.

Bryman, A. (2012). Social research methods (4th ed.). Oxford, England: Oxford University Press.

Butcher, J. (2003). The moralisation of tourism: Sun, sand ... and saving the world? New York, NY: Routledge.

Cattunar, A. (2012). Il calendario conteso: Commemorazioni di confine, tra manipolazioni della storia e costruzioni delle identità nel secondo dopoguerra. Acta Histriae, $20(4), 703-720$. 
Clark, L. B. (2006). Placed and displaced: Trauma memorials. In L. Hill \& H. Paris (Eds.), Performance and place (pp. 129-138). London, England: Palgrave Macmillan.

Cocco, E. (2010). Borderland mimicry: Imperial legacies, national stands and regional identity in Croatian Istria after the nineties. Narodna umjetnost: hrvatski časopis za etnologiju i folkloristiku, 47(1), 7-28.

D'Alessio, V. (2012). Dynamics of identity and remembrance in Trieste esodo, foibe and the complex memory of Italy's oriental border. In D. Pauković, V. Pavlaković, \& V. Raos (Eds.), Confronting the past: European experiences (pp. 285-315). Zagreb, Croatia: Political Science Research Centre.

Douglas, N., Douglas, N., \& Derrett, R. (Eds.). (2001). Special interest tourism: Context and cases. Melbourne, Australia: Wiley.

Drvenkar, N., Banožić, M., \& Živić, D. (2015). Development of memorial tourism as a new concept: Possibilities and restrictions. Tourism and Hospitality Management, 21(1), $63-77$.

Duda, I. (2000). Elementi kozmopolitizma u Puli između 1850. i 1918. godine. Radovi, 32-33(1), 105-116.

Dukovski, D. (2001). Rat $i$ mir istarski: model povijesne prijelomnice 1943-1955. Pula, Croatia: CAsH.

Dukovski, D. (2010). Atentat na britanskoga brigadira Roberta de Wintona u Puli 10. veljače 1947. Časopis za suvremenu povijest, 42(3), 671-691.

Dukovski, D. (2011). Povijest Pule: deterministički kaos i jahači Apokalipse. Pula, Croatia: Istarski ogranak Društva hrvatskih književnika.

Dunkley, R. A., Morgan, N., \& Westwood, S. (2007). A shot in the dark? Developing a new conceptual framework for thanatourism. Asian Journal of Tourism and Hospitality Research, 1(1), 54-63.

Dunkley, R., Morgan, N., \& Westwood, S. (2011). Visiting the trenches: Exploring meanings and motivations in battlefield tourism. Tourism Management, 32(4), 860-868.

Ferenc, T. (1966). Ustanovitev operacijske zone »Jadransko primorje« jeseni 1943. leta. Zgodovinski časopis, 19-20, 401-419.

Filipčič, R. (2011). 4. PŠTo Južnoprimorske pokrajine v vojni za Slovenijo. Veteran, 16(46), 20-22.

Foley, M., \& Lennon, J. J. (1996). JFK and dark tourism: A fascination with assassination. International Journal of Heritage Studies, 2(4), 198-211.

Foley, M., \& Lennon, J. J. (1997). Dark tourism: An ethical dilema. In M. Foley, J. J. Lennon, \& G. Maxwell (Eds.), Hospitality, tourism and leisure management (pp. 153164). London, England: Cassell.
Freeman, L. A. (2014). The Manhattan project time machine: Atomic tourism in Oak ridge, Tennessee. In B. Sion (Ed.), Death tourism: Disaster sites as recreational landscape (pp. 54-74). London, England: Seagull Books.

Frost, W., \& Laing, J. (2013). Commemorative events: Memory, identities, conflict (1st ed.). London, England: Routledge.

Getz, D. (2008). Event tourism: Definition, evolution, and research. Tourism Management, 29(3), 403-428.

Gosar, A., Koderman, M., \& Rodela, M. (Eds.) (2015). Dark tourism: Post-WWI destinations of human tragedies and opportunities for tourism development; proceedings of the international workshop. Koper, Slovenia: University of Primorska Press.

Gusterson, H. (2004). Nuclear tourism. Journal for Cultural Research, 8(1), 23-31.

Hall, C. M., \& Weiler, B. (1992). Introduction: What's so special about special interest tourism? In B. Weiler \& C. M. Hall (Eds.), Special-Interest Tourism (pp. 1-14). London, England: Belhaven Press.

Herman Kaurić, V. (2015). The First World War in Croatia: More or less known facts. Review of Croatian History, $10(1), 7-22$.

Hertzog, A. (2012). War battlefields, tourism and imagination. Via: Tourism Review. Retrieved from https:/doi .org/10.400o/viatourism.1283

Hrobat Virloget, K. (2015). Breme preteklosti: spomini na sobivanje in migracije $\mathrm{v}$ slovenski Istri po drugi svetovni vojni. Acta Histriae, 23(3), 531-554.

Hrobat Virloget, K., \& Čebron Lipovec, N. (2017). Heroes we love? Monuments to the National liberation movement in Istria between memories, care, and collective silence. Studia Ethnologica Croatica, 29(1), 45-71.

Hughes, R. (2008). Dutiful tourism: Encountering the Cambodian genocide. Asia Pacific Viewpoint, 49(3), 318-330.

Jokić, G., \& Čudov, D. (1986). Jugoslavija - spomenici revolucije: turistički vodič. Belgrade, Serbia: Turistička štampa.

Kalčić, M. (2016). Počeci kinofikacije Pule (do početka Velikoga rata): prvi puljski stalni kinematografi i prvo erotsko kino. Histria, 6(6), 93-143.

Kavrečič, P. (2009). Biseri avstrijske riviere: Opatija, Gradež, Portorož. Začetki modernega turizma na severnem Jadranu. Kronika, 57(Special issue), 113-128.

Kavrečič, P. (2011). Pričevalci preteklosti avanturisti in drugi popotniki na Krasu in v Istri pred modernim turizmom. Acta Histriae, 19(4), 683-702.

Kavrečič, P. (2015). Turizem v Avstrijskem primorju: zdravilišča, kopališča in kraške jame (1819-1914). Koper, Slovenia: Založba Univerze na Primorskem. 
Kavrečič, P. (2017). 'Sacro pellegrinaggio:' Visits to World War I memorials on the Soča/Isonzo Front in the interwar period. Etnološka Tribina, 47(40), 141-16o.

Kennell, J., Šuligoj, M., \& Lesjak, M. (2018). Dark events: Commemoration and collective memory in the former Yugoslavia. Event Management, 22(6), 945-963.

Keyes, M. (2012). War tourism: Shaping memory and perception in post-war vietnam. Retrieved from https:// soundideas.pugetsound.edu/summer_research/164

Kim, J.-H. (2013). A cross-cultural comparison of memorable tourism experiences of American and Taiwanese college students. Anatolia: An International Journal of Tourism and Hospitality Research, 24(3), 337-351.

Klabjan, B. (2010). Nation and commemoration in the Adriatic: The commemoration of the Italian unknown soldier in a multinational area. Acta Histriae, 18(3), 399-424.

Knez, K. (2010). L'Istria nel viaggio di Charles Yriarte. Quaderni, 21, 7-46.

Kosmač, M. (2018). Building Italianità in Northern Adriatic: The case of organized migration of population from Pola/Pula. Nationalities Papers, 46(6), 992-1007.

Kravanja, B. (2018). Dediščina soške fronte kot izhodišče za razmislek o sodobnih pristopih $\mathrm{k}$ dediščinski politiki. Etnolog, 28, 105-122.

Kruja, D., \& Gjyrezi, A. (2011). The special interest tourism development and the small regions. Turizam, 15(2), 7789.

Lennon, J. J., \& Foley, M. (1999). Interpretation of the unimaginable: The us Holocaust memorial museum, Washington, DC, and 'dark tourism.' Journal of Travel Research, 38(1), 46-50.

Lennon, J. J., \& Foley, M. (200o). Dark tourism: The attraction of death and disaste (1st ed.). London, England: Cengage Learning E MEA.

Lipušček, U. (2012). Sacro egoismo: Slovenci v krempljih tajnega londonskega pakta 1915. Ljubljana, Slovenia: Cankarjeva založba.

Majušević, M. (2012). 37. Pazinski memorijal, znanstvenostručni skup, Spomen-dom Pazin, 30. rujna 2011. Histria, 2(2), 444-448.

Mandić, D. (2006). Austrougarski mornaričk zrakoplovni arsenal i mornaričke zrakoplovne postaje u pulskom akvatoriju. In M. Černi (Ed.), Iz povijesti Pulske luke: zbornik radova (pp. 192-212). Pula, Croatia: Lučka uprava Pula.

Mansfeld, Y., \& Korman, T. (2015). Between war and peace: Conflict heritage tourism along three Israeli border areas. Tourism Geographies, 17(3), 437-46o.

Marsetič, R. (2006a). Il porto di Pola, il cantiere navale
Scoglio olivi e l'arsenale durante il periodo italiano (nel 150. anniversario della fondazione dell'Arsenale di Pola 1856-2006). Quaderni, 17(1), 7-114.

Marsetič, R. (2006b). Pulska luka u vrijeme Italije. In M. Černi (Ed.), Iz povijesti Pulske luke: zbornik radova (pp. 213-245). Pula, Croatia: Lučka uprava Pula.

Marsetič, R. (2013). Analisi dell'apparato militare austroungarico a Pola durante la Prima guerra mondiale. Atti, 42(1), 483-520.

Marsetič, R. (2014). Le strutture ospedaliere comunali e provinciali a Pola durante il governo austriaco. Atti, 43(1), 273-316.

Mustapić, M., \& Balabanić, I. (2018). 'Mjesto sjećanja' ili izborna kampanja? Analiza sadržaja hrvatskih medija prije parlamentarnih izbora 2015. Društvena istraživanja, 27(3), 431-451.

Neuendorf, K. A. (2017). The content analysis guidebook (2nd ed.). Thousand Oaks, cA: Sage.

Nišić, V., \& Plavšić, D. (2014). The role of media in the construction of social reality. Sociološki Diskurs, 7(4), 73-81.

O'Rourke, P. J. (1988). Holidays in hell. London, England: Picador.

Pavlaković, V., \& Perak, B. (2017). How does this monument make you feel? Measuring emotional responses to war memorials in Croatia. In T. S. Andersen \& B. TörnquistPlewa (Eds.), Transcultural mediation and reception: The twentieth century in European memory (pp. 268-304). Leiden, the Netherlands: Brill.

Podoshen, J. S., Venkatesh, V., Wallin, J., Andrzejewski, S. A., \& Jin, Z. (2015). Dystopian dark tourism: An exploratory examination. Tourism Management, 51, 316-328.

Preece, T., \& Price, G. (2005). Motivations of participants in dark tourism: A case study of Port Arthur, Tasmania. In C. Ryan, S. Page, \& M. Aicken (Eds.), Taking tourism to the limits: Issues, concepts and managerial perspectives (pp. 191-197). Oxford, England: Elsevier.

Purini, P. (2012). Esodi dalla Venezia Giulia: Cause politiche e motivazioni sociologiche. Acta Histriae, 2o(3), 417-432.

Radošević, M. (2010). Pregled izvještaja pulskog dnevnika Corriere Istriano (listopad-prosinac 1943.) o stradalima $\mathrm{u}$ istarskim fojbama i boksitnim jamama nakon kapitulacije Italije 8. rujna 1943. godine. Problemi sjevernog Jadrana, 10, 89-107.

Riffe, D., Lacy, S., \& Fico, F. (2005). Analyzing media messages: Using quantitative content analysis in research (2nd ed.). Mahwah, NJ: Lawrence Erlbaum Associates.

Robb, E. M. (2009). Violence and recreation: Vacationing in the realm of dark tourism. Anthropology and Humanism, $34(1), 51-60$. 
Robinson, M., \& Novelli, M. (2005). Niche tourism: An introduction. In Niche Tourism: Contemporary issues, trends and cases (pp. 1-11). London, England: Routledge. Rogoznica, D. (2011). Iz kapitalizma v socializem: gospodarstvo cone B Svobodnega tržaškega ozemlja: 1947-1954. Koper, Slovenia: Pokrajinski arhiv Koper.

Rojek, C. (1994). Ways of escape. Lanham, MD: Rowman \& Littlefield.

Ryan, C. (Ed.). (2007). Battlefield tourism: History, place and interpretation. London, England: Elsevier Science.

Seaton, A. V. (1996). Guided by the dark: From thanatopsis to thanatourism. International Journal of Heritage Studies, 2(4), 234-244.

Simone-Charteris, M., Kirkpatrick, J., \& McLaughlin, C. (2018). An investigation of the differences that exist between generations in relation to supporting dark tourism in Northern Ireland. DBS Business Review, 2, 69-88.

Spirito, P. (2002). L'ultimo viaggio del 'Baron Gautsch.' Trieste, Italy: LINT.

Stone, P. R. (2006). A dark tourism spectrum: Towards a typology of death and macabre related tourist sites, attractions and exhibitions. Turizam, 54(2), 145-160.

Stone, P. R. (2016). Enlightening the 'dark' in dark tourism. Interpretation Journal, 21(2), 22-24.

Šarić, T. (2015). Bijeg iz socijalističke Jugoslavije - ilegalna emigracija iz Hrvatske od 1945. do početka šezdesetih godina 20. stoljeća. Migracijske i etničke teme, 31(2), 195220.

Štetić, S., Šimičević, D., \& Ćurčić, N. (2013). Posebni oblici turizma. Belgrade, Serbia: Forma B.

Šuligoj, M. (2015a). Nekatere ključne okoliščine (preteklega) razvoja turizma v Istri/Neke ključne okolnosti (protek$\log$ ) razvoja turizma u Istri. In M. Šuligoj (Ed.), Retrospektiva turizma Istre (pp. 17-48). Koper, Slovenia: Založba Univerze na Primorskem.

Šuligoj, M. (Ed.). (2015b). Retrospektiva turizma Istre. Koper, Slovenia: Založba Univerze na Primorskem.

Šuligoj, M. (2016). Memories of war and warfare tourism in Croatia. Annales: Series Historia et Sociologia, 26(2), 259270 .
Šuligoj, M. (2017). Warfare tourism: An opportunity for Croatia? Economic Research, 30(1), 439-452.

Šuligoj, M. (2018). Characterising the flows of Slovenian tourists within the former Yugoslavia with respect to post-communist 'nostalgic context.' Moravian Geographical Report, 26(1), 14-26.

Šuran, F. (2016). Slobodno vrijeme, putovanje i turizam: sociološki pristup. Buje, Croatia: Happy.

Tarlow, P. (2005). Dark tourism: The appealing 'dark' side of tourism and more. In M. Novelli (Ed.), Niche tourism: Contemporary issues, trends and cases (pp. 47-58). Amsterdam, the Netherlands: Elsevier.

Todero, F. (2010). Politiche della memoria della Grande guerra: Il caso della Venezia Giulia. Acta Histriae, 18(3), 383-398.

Trauer, B. (2006). Conceptualizing special interest tourism: Frameworks for analysis. Tourism Management, 27(2), 183-200.

Tunjić, F. (2004). Vmesna Evropa: konfliktnost državnih teritorialnih meja. Koper, Slovenia: Univerza na Primorskem / Znanstveno-raziskovalno središče / Zgodovinsko društvo za južno Primorsko.

Violante, A. (2009). The past does not seem to pass at the Venezia Giulia border. In M. Sobczyński (Ed.), Historical regions divided by the borders: General problems and regional issues (pp. 97-112). Łódź, Poland: University of Łódź.

Wise, N. A. (2011). Post-war tourism and the imaginative geographies of Bosnia and Herzegovina, and Croatia. European Journal of Tourism Research, 4(1), 5-24.

Wong, K. K. F., \& Cheung, P. W. Y. (1999). Strategic theming in theme park marketing. Journal of Vacation Marketing, 5(4), 319-332.

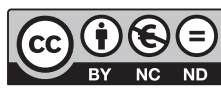

This paper is published under the terms of the Attribution- NonCommercial-NoDerivatives 4.0 International (CC B Y-NC-ND 4.0) License. 